\title{
Impact of Retail Service Quality and Store Service Quality on Patronage Intention towards Organized Retail Industry
}

\author{
P.S.Venkateswaran ${ }^{1}$, Suja Sundram ${ }^{2}$ \\ ${ }^{1}$ Department of Management Studies, PSNA College of Engineering and Technology, Tamil Nadu, India \\ ${ }^{2}$ Department of Business Administration, Jubail University College for Female Branch, \\ Jubail industrial city, Kingdom of Saudi Arabia. \\ venkatespsna07@gmail.com ${ }^{1}$, sundrams@ucj.edu.sa ${ }^{2}$
}

Article History: Received: 10 November 2020; Revised: 12 January 2021; Accepted: 27 January 2021;

Published online: 05 April 2021 Abstract: Purpose: A proper service increases the customer satisfaction and positive word of mouth. The aim of this paper is
to find out the impact of retail service quality and store service quality on patronage intention and word of mouth towards
organized retail industry.
Design/methodology/approach: The study data were collected from [location masked for blind review] using a structured
questionnaire. A sample of 419 was used. A structural model was developed for analysis to find out the linkage between
study variables.
Findings/results: Findings reveal that retail service quality and store service quality are increasing the customer satisfaction.
The findings showed that retail service quality, store service quality, and customer satisfaction significantly impact patronage
intention and word of mouth. Problem solving is the major issue faced by the retail stores. Hence they have to take immediate
action towards it to maintain their loyal customer base
Practical implications: Problem-solving is not having significant relationships with customer satisfaction. Store managers
have to create a pleasant experience and amplify the strength factors to create a bond between the store and the customers
Originality/value: This paper is helpful to the retail store managers as well as new entrepreneurs who are going to start a
new venture in the retail business.

Keywords:Supermarkets, Retail service quality (RSQ), Store service quality (SSQ), Store patronage intentions (SPI), Customer satisfaction (CS),Word of mouth (WOM), [location masked for blind review] .

\section{Introduction}

The Indian retail sector contributes substantially to India's economy by 1.1 trillion in 2020 and supports 15.2 million people with jobs (Media reports, 2019). By 2024, India's e-commerce market will hit US\$ 99 billion, rising at a 27 percent CAGR compared to 2019. The supermarket sector is rapidly evolving and updating shop formats (Diallo et al., 2015) (Shi et al., 2018). The retail sector has to face a fierce strategic battlefield because of falling profit margins (Kamran-Disfani et al., 2017). Such massive rivalry helps shoppers to have more chances to go to individual retailers. '90\% of global retail transactions are now made in physical stores' (eMarketer, 2017). As such, supermarkets must now switch from suppliers of products to suppliers with exclusive product deals and service quality to cope with internet shopping ease, above what shoppers could consider online, with a unique in-store experience (Hernant and Rosengren, 2017). Today, providing a good and expected service is a mandatory one for the retail stores.

The level of service is absolute since it impacts customer retention and engagement and sustainability for retailers (Seth et al., 2005). In order to understand unique quality problems impacting customer loyalty from five dimensions (personal engagement, accountability, efficiency, regulation, and tangibility), the SERVQUAL assessment framework has been successfully implemented (Sunil et al., 2018; Sharma and Srivastava, 2018; Shafiq et al., 2019). Research studies have established that the aspects of service quality are precedents of customer satisfaction (Lau et al., 2013) and that customer satisfaction is substantially connected to problem solving and policy (Mengi, 2009), as well as the physical component, efficiency, and personal interaction (Zaim et al., 2010). Some experiments have shown that human communication is strongly associated with consumer loyalty, accompanied by policy and physical factors (Siddiqi, 2011).

A few other researchers say that consumer satisfaction enhances loyalty (Casidy and Wymer, 2015; Kasiri et al., 2017; Srivastava and Kaul, 2016; Su et al., 2016). Service quality is the primary tool to ensure and providing a competitive edge service to their customers than their rivals (Prakash, 2019; Roy et al., 2019; Jain \& Aggarwal, 2018; Prentice et al., 2018; Sarker \& Ashrafi, 2018; Hsiao, 2018).

Due to heavy competition, retailers face difficulties maintaining their loyal customers (Hegner- Kakar et al., 2018). It is complicated and tough today to retain the customers (Kamran-Disfani et al., 2017). The retail sector faces a stiff battle among other industries in holding and keeping their existing customers in developing 
countries (Mahmoud et al., 2019; Grosso et al., 2018; Alam, 2018; Konuk, 2018). The researcher therefore agreed to assess the effect of the quality of retail outlet and store environment on the intention of patronage towards organized retail stores in the selected towns of Tamil Nadu, India.

\section{Literature Review}

\subsection{Retail Service Quality (RSQ)}

Today, customers expect high-quality services from their organization (Chen et al., 2019; Osakwe, 2019). Dabholkar et al. (1996) introduced the Retail Service Quality Scale to measure retailer services in five dimensions: physical aspect (such as the layout of the shop and the ease provided to consumers by the architecture of a store), continuity (combination of upholding promises, i.e. continuity in distribution of products and services; doing the right to service; i.e. the supply of goods and error-free sales transactions), problemsolving (handling refunds and transfers as well as complaints), policy (hours of operation, approved sales transactions) (captures whether salespersons inspire confidence with their knowledge and expertise in customers regarding a purchase, treat them courteously and provide help when needed). This scale was used to measure the services provided by retail outlets by different researchers (Bhat, 2016). Retail firms should comprehend retail customers' perceptions, evaluate the perceptions periodically, and develop quality improvement plans. For retail stores to know about their performance on various service quality dimensions, appropriate service quality measures are needed. From the reviews, the variable for the current study was considered.

\subsection{Store service quality (SSQ)}

The in-store environment often defines whether customers see products as integrated, whether the perspective of the shop delivers on the corporate pledge (Khan and Rahman, 2015). The relationship between customers and retailers is important for the sense-making of sustainable consumption by consumers (Lehner, 2015). Porral et al. (2015) evaluated variables like price, familiarity, and picture of the shop empirically. They noticed that the familiarity of private label labels strongly affects the purchasing of a shop. Studies have found that in-store experience impacts the reputation and faith of the store and the level of potential shopping intentions of customers (Ng et al., 2014; Yoon, 2013). With Diallo M. F. (2012) found that the views of shop photographs have a huge effect on PLB's direct or indirect buying. Wu et al. (2011) analyzed that aspects of the store picture such as product range, product consistency, price, money value, and environment of the store had a clear and positive impact on their buying behavior.

Both consumer-retailer experiences are included in the in-store experience, spanning several touch points inside a store, resulting in shoppers acquiring knowledge to aid them in decision-making (Duncan and Moriarty, 2006). Torlak et al. (2010) noted that in order to satisfy the needs of customers in a retail setting, retailers must stress the value of product quality and service quality. The in-store experience of a customer depends on the behavior of a person, including consumer beliefs or reasons for shopping (Carpenter and Moore, 2006), and also tangible and intangible store characteristics (atmospherics, store design, assortment, pricing, and sales personnel). The element for the current analysis was known from the evaluations.

\subsection{Store patronage intentions (SPI)}

Service providers in rural areas tend to be small businesses oriented to local demand, whereas those in urban communities can offer scale or specialized functions (Halseth and Ryser 2006). Convenience stores, grocery stores, and supermarkets fall along an increasing gradient of affordability, presumably related to store size (Rimkus et al. 2015). However, precisely how to store type is associated with rural prices remains unclear (Ko et al., 2018).

The close relationship between retail stores and consumers is projected to affect the behaviour of shoppers towards retail stores. When shoppers build a retail bond, they see the store as part of themselves and create excellent suggestions and thoughts about the store (Park et al., 2010). Reporting that supermarket connection, in terms of general affection, affects re-patronage intentions in a grocery store environment, Vlachos and Vrechopoulos (2012). Store connections were thus anticipated to be favorably linked to the wishes of store patronage. From the reviews, the variable for the current study was considered.

\subsection{Customer satisfaction (CS)}


Today, the business world revolves around customer-centric and paying substantial attention to customer satisfaction (Ali \& Raza, 2017). Retail business was concentrated on significant customer satisfaction (Yeng \& Yazdanifard, 2015; Smigielska \& Oczkowska, 2017). Satisfied customers support organizations in many ways for further business (Kasiri et al., 2017). As per Wantara (2015), the disparity between the preferences of consumers about a product or service and real results is assumed to be customer satisfaction. Loyal consumers are happy to pay more with good buying intentions and products that are barely evolving (Evanschitzky et al., 2012).

\subsection{Word of mouth (WOM)}

WOM communication refers to 'informal communication between a supposed non-commercial communicator and a recipient about a brand, a product, an entity, or a service, from person to person. (In 2001, Harrison-Walker). Daily customers spread WOM relative to new customers because they had a positive experience, making them a reliable source of information for outsiders on brands, products or services (Karjaluoto et al., 2016). Their in-store interactions can decide the degree of happiness and potentially result in a desire to share good WoM with others. A favorable association between CS and grocery behaviour towards grocery stores was found in previous studies (Nair, 2018; Fernandes and Calamote, 2016). Therefore, it is important to know how the happiness of consumers impacts their revision and WOM intentions. The positive correlation between WOM referrals to new consumer acquisitions was recorded in past study (Trusov et al., 2009). The spread of optimistic WOM thus encourages firms to increase their market share with the awareness of the brand. From the reviews, the variable for the current study is considered (Xu \& Li, 2016).

\section{Methodology}

\subsection{Research Design}

This analysis is exploratory and innocent. Researchers quantified the data gathered from the respondents on the level of service and patronage purpose of integrated retail stores. This quantitative analysis review is a 'oneshot' cross-sectional research. Researchers obtained responses from respondents at a particular period in time.

\subsection{Sampling Design and size}

The study area was [location masked for blind review] city, Tamilnadu. The study's target population was all the shoppers within 18-65 who shop at the multi-brand department retail stores in [location masked for blind review] city. A purposive sampling method was adopted. A sample of 50 from 10 retail stores (50 per store) planned. Hence a total of 500 samples decided to collect for the study. After collecting the data, unanswered questionnaires were removed from the samples. 437 filled questionnaires were received.18 improperly answered questionnaires were removed. Finally, a sample of 419 was used for the data analysis. The following hypothesis was framed for further analysis.

H1 - There is a positive relationship between retail service quality and customer satisfaction.

H1a There is a positive relationship between Physical aspect and customer satisfaction.

$\mathrm{H} 1 \mathrm{~b}$ There is a positive relationship between reliability and customer satisfaction.

$\mathrm{H} 1 \mathrm{c}$ There is a positive relationship between problem-solving and customer satisfaction.

H1d There is a positive relationship between policy and customer satisfaction.

H1e There is a positive relationship between personal interaction and customer satisfaction.

$\mathrm{H} 2$ - There is a positive relationship between store service quality and customer satisfaction

$\mathrm{H} 3$ - There is a positive relationship between customer satisfaction and patronage intention

$\mathrm{H} 4$ - There is a positive relationship between customer satisfaction and word of mouth. 
Proposed conceptual framework

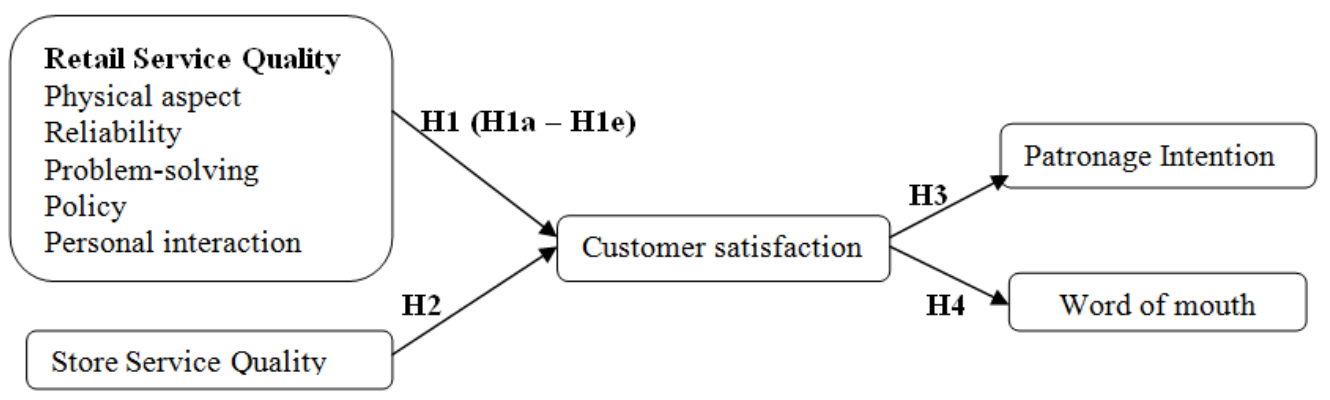

Figure 1. Proposed Conceptual Framework

\section{Results}

Table 1.Socio economic details of the respondents

\begin{tabular}{|c|c|c|c|}
\hline Characteristic & Socio economic details & Frequency $(n=419)$ & Percentage \\
\hline \multirow[t]{4}{*}{ Age of the employees } & Below 25 & 78 & 18.6 \\
\hline & $26-35$ & 157 & 37.5 \\
\hline & $36-45$ & 118 & 28.2 \\
\hline & $46-60$ & 66 & 15.8 \\
\hline \multirow[t]{2}{*}{ Gender of the employees } & Male & 297 & 70.9 \\
\hline & Female & 122 & 29.1 \\
\hline \multirow[t]{3}{*}{ Marital status } & Married & 198 & 47.3 \\
\hline & Unmarried & 165 & 39.4 \\
\hline & Single & 56 & 13.4 \\
\hline \multirow[t]{5}{*}{ Educational qualification } & SSLC & 30 & 7.2 \\
\hline & Higher Secondary & 36 & 8.6 \\
\hline & Diploma/ITI & 119 & 28.4 \\
\hline & Degree & 120 & 28.6 \\
\hline & Post Graduate & 54 & 12.9 \\
\hline \multirow[t]{4}{*}{ Monthly income level [in rupees] } & Below 15000 & 78 & 18.6 \\
\hline & $15001-30000$ & 183 & 43.7 \\
\hline & $30001-45000$ & 117 & 27.9 \\
\hline & 45001 and above & 41 & 9.8 \\
\hline
\end{tabular}

Source: Primary data

Table1 shows the socio-economic details of the respondents. 37.5 percent of the respondents are in the 26-35 years, age group. 28.2 and 18.7 percent of the respondents belong to $36-45$ and below 25 age groups, respectively. 15.85 percent of the respondents are in the 46-60 years category. 70.95 percent of the respondents are Male, and 29.15 percent of the respondents are female. 47.3 percent of the respondents are married. 39.4 percent of the respondents have unmarried, 13.4 percent are single, 28.6, and 28.4 percent are degree holders and Diploma/ITI Certificate holders. 8.6 and 7.2 percent of the respondents are higher secondary and SSLC, respectively. 43.7 percent of the respondents are in the $15001-30000$ rupees monthly income level. 27.9 and 18.6 percent of the respondents are in the 30001-45000 and below 15000 rupees monthly income level, respectively.9.8 percent of the respondents are in 45001 and above rupees monthly income level.

Table 2.Reliability analysis

\begin{tabular}{|l|c|c|c|c|}
\hline \multicolumn{1}{|c|}{ Variable } & No. of items & Mean & Standard Deviation & Cronbach's alpha \\
\hline Retail Service Quality & 22 & 3.719 & .957 & 0.917 \\
\hline Store Service Quality & 6 & 3.904 & .811 & 0.893 \\
\hline Store patronage intentions & 6 & 3.866 & 1.034 & 0.846 \\
\hline Customer satisfaction & 8 & 3.792 & 1.015 & 0.931 \\
\hline Word of mouth & 4 & 3.821 & .833 & 0.884 \\
\hline
\end{tabular}

Source: Primary data 
For the analysis variables, Table 2 displays the mean, standard deviation and Cronbach values. Pearson's coefficient of correlation ( $r$ ) was introduced to calculate the frequency of the interaction between the two variables. The researcher decided to determine the relationships between RSQ dimensions (retail service quality, store environment, store patronage intentions, customer satisfaction, and word of mouth as independent variables) and customer satisfaction as a Direct Variable. Multiple regression analysis was done to analyze various independent variables '(RSQ, SSQ, PI) concurrent influences on a dependent variable, as per Sekaran and Bougie (2016). (CS and WOM).

Table 3.Pearson correlation result of Retail Service Quality (RSQ) dimensions and customer satisfaction (CS)

\begin{tabular}{|l|c|c|c|c|c|}
\hline $\begin{array}{l}\text { Retail Service Quality (RSQ) } \\
\text { dimensions }\end{array}$ & $\begin{array}{c}\text { Physical } \\
\text { aspect }\end{array}$ & Reliability & Problem-solving & Policy & $\begin{array}{c}\text { Personal } \\
\text { interaction }\end{array}$ \\
\hline Physical aspect & 1 & & & & \\
\hline Reliability & $.832^{* *}$ & 1 & & & \\
\hline Problem-solving & .107 & $.685^{* *}$ & 1 & & \\
\hline Policy & $.522^{* *}$ & $.648^{* *}$ & $.517^{* *}$ & 1 & \\
\hline Personal interaction & $.609^{* *}$ & $.737^{* *}$ & $.603^{* *}$ & $.725^{* *}$ & 1 \\
\hline
\end{tabular}

* Significant at $\mathrm{p}<0.001$ level

The correlation coefficient (r) of RSQ dimensions (Table 3) suggests that there was positive and significant relationship between RSQ dimensions and customer satisfaction $(r=0.832,0.522,0.609$, p-value $<0.001)$. To find out the linkage between all the study variables a structural equation model was adapted. Results indicate that customer satisfaction is highly reliant on multiple factors. Retail Service quality is a major influencing factor to induce customers towards retail stores. The role of patronage intention and store service quality is also the factors to be considered by the retail stores to attract new and existing customers. The result of the SEM model and proposed hypotheses is shown in Table 4.

Table 4.Summary of hypotheses result

\begin{tabular}{|l|c|c|c|}
\hline \multicolumn{1}{|c|}{ Study variables } & Coefficient $(\boldsymbol{\beta})$ & t-value & Hypotheses Result \\
\hline Retail service quality $\rightarrow$ Customer satisfaction & .188 & 5.931 & H1 Supported \\
\hline Physical aspect $\rightarrow$ customer satisfaction & .508 & 3.527 & H1a Supported \\
\hline Reliability $\rightarrow$ customer satisfaction & .242 & 6.613 & H1b Supported \\
\hline Problem-solving $\rightarrow$ customer satisfaction & .177 & 1.324 & H1c rejected \\
\hline Policy $\rightarrow$ customer satisfaction & .154 & 3.083 & H1d Supported \\
\hline Personal interaction $\rightarrow$ customer satisfaction & .068 & 4.820 & H1e Supported \\
\hline Store service quality $\rightarrow$ customer satisfaction & .155 & 5.044 & H2 Supported \\
\hline Customer satisfaction $\rightarrow$ Patronage intention & .241 & 3.919 & H3 Supported \\
\hline Customer Satisfaction $\rightarrow$ Word of mouth & .103 & 9.116 & H4 Supported \\
\hline CFI,
\end{tabular}

CFI, comparative fit index; TLI, Tucker-Lewis index; RMSEA, root mean square error of approximation. $\mathrm{CFI}=.967, \mathrm{TLI}=0.954, \mathrm{RMSEA}=.026$.

In this study, customer satisfaction, patronage intention, and word of mouth have been extensively studied with retail service quality variables and store service quality simultaneously, whereas other studies have been scarcely done. SSQ is the major influencing factor in patronage intentions and customer satisfaction. Structural model shows positive and significant relationships between RSQ dimensions of the physical aspect, reliability, policy, personal interaction, and customer satisfaction. However, as one of the dimensions in RSQ, problemsolving is not significantly correlated with customer satisfaction. These results reflect similar results (Barnes et al., 2016; Nadiri et al., 2008; Nyadzayo and Khajehzadeh, 2016).

From the table 4, Under RSQ, the Physical aspect $(\beta=0.508, \mathrm{P}>0.001)$ have a positive and significant effect on customer satisfaction.Hence, Physical aspect plays a vital role in customer satisfaction. Ltifi \& Gharbi (2015) has a similar results in their study about 'physical appearance in retail service'- "internal logistics performance of a point of sale has positive and significant effects on happiness and customer satisfaction". Otterbring et al. (2014) reflected the same result in their study "Vision (im) possible? The effects of in-store signage on customers' visual attention'. Other researchers (Maggioni, 2016; Quach, Jebarajakirthy, \& Thaichon, 2017; Sin Jie Jiang 2017) also have similar results for Physical aspect and customer satisfaction. Proper parking facilities with free parking should be made available for customers. Entertainment like game rooms for kids, parks with small playing pools will, increase the staying time of the customers inside the store. 
Under RSQ, reliability $(\beta=0.242, \mathrm{P}>0.001)$ have a positive and significant effect on customer satisfaction. Beneke et al. (2012) have similar results in their study 'examining the effect of retail service quality dimensions on customer satisfaction and loyalty: The supermarket shopper's case. Under RSQ, the role of Problem-solving (Customer complaints, returns, and exchanges) is vital for the retail store's smooth run.

In this study, problem-solving $(\beta=0.177, \mathrm{P}<0.001)$ is not having significant relationship with customer satisfaction. Under RSQ, Policy $(\beta=0.154, \mathrm{P}>0.001)$ and Personal interaction $(\beta=0.068, \mathrm{P}>0.001)$ have a positive and significant relationship with customer satisfaction.Stores have to make a policy that weekly/monthly promotional activities should be arranged to bring more customers on weekdays and avoid the rush on the weekends. Same results were reflected in Terblanche NS and Boshoff C, (2006) study.

Store service quality $(\beta=0.155, \mathrm{P}>0.001)$ has a positive and significant relationship with customer satisfaction. This result was similar to the studies of (Ertekin, N. et al. 2019; Arif Hasan (2018); Suja R. Nair, 2017; Alić, A., Agić, E., \& Činjarević, M. 2017).

Customer satisfaction $(\beta=0.241, \mathrm{P}>0.001)$ shows a positive and significant relationship with patronage intention (Suja R. Nair, 2017; Sonali Diddi and Linda S. Niehm. 2017). Satisfied customers were always showing their affinity to a particular store. In this study, Customer satisfaction has a direct influence on Patronage intention, which were reflected in other studies (Özgür Çengel, Ilgin Çakiroğlu,2020; Aldousari Abdullah A.and El-Sayed Ismail M, 2017). Customer satisfaction $(\beta=0.241, \mathrm{P}>0.001)$ shows a positive and significant relationship with word of mouth communication.

The result shows that retail service quality, store service quality, and customer satisfaction significantly impact patronage intention and word of mouth. This result reflects the study of Neale Slack et al. (2020). The significant findings of this study indicate that customer satisfaction plays the most crucial role in promoting customer purchase intention. Customer satisfaction directly influenced word of mouth and was also found to be effective using store brand purchases (Chiu Y.K., Lin. C .Y, 2012). A positive word of mouth could positively increase the store value and store image. Customers responded that the store where they are regularly purchasing has no financial, psychological, and physical risk associated. The store always increases their purchase intention positively, and they are ready to visit the store repeatedly. They also responded that they would recommend this store to their friends and relatives due to the new varieties of goods and excellent services.

\section{Conclusion}

The physical aspect, Reliability, Policy, and Personal interaction were influencing customer satisfaction more effectively in the store retail outlet. Problem-solving is the major weakness found from the study that the retail managers immediately have to take care. Proper training in answering the customers' questions with politeness, helping the customers eagerly, clearing and settle the accounts fast and clean, creating a positive image about the products/brands, and selling the products with product knowledge.

Reliability is the primary factor in the retail store outlet. Customers are going to interact and enjoy the service in person. If they can understand that the services, quality, and quantity of the products, price factors are reliable, increasing their satisfaction and positive word of mouth. Hence, the retail store has to be cautious about its service offering to its customers. Retail store managers have to maintain a regular customer record. They can send a gift/voucher at the time of a family member's birthday or other functions to maintain a good rapport with them. Prompt service (door) delivery by the store may positively increase the store image and increase patronage intention.

In physical aspects, the ambiance should be neat and clean, easy to move inside the store, trolley and other carrying facilities, product display cards, product placements, easy to take are the essential factors to be considered. Restroom facilities were available in only a few retail outlets. Customers expect a restroom facility inside the retail store premises, making the customers (coming with kids, Diabetics) can stay some more time in the store for their purchases.

The policy should be framed to provide the best service in a better way. The store staff takes care of certain facilities like customer's properties care, secure transaction, solve problems immediately (if any), easy check out process, individual attention, and response immediately are highly needed and expected by the customers.

Today the customers are not purchasing - they are shopping. Hence they expect the retail Store should be in modern, visually appealing physical facilities, well displayed products, and store atmosphere should be elegant, 
uninterrupted power supply and good parking facility. Store brands are pushed in the retail Stores through the sales person's effective selling methods. Hence the retails agencies should train the sales person accordingly to influence the customers to make the purchase more in their store.

From this study, store managers get lot of insights on how to retain the customers by making customer relationships through customer satisfaction. Store managers have to create a pleasant experience and amplify the strength factors to create a bond between the store and the customers.

From the study and findings, certain conclusions were drawn. Factors such as physical aspect, reliability, policy, personal interaction are significant predictors to evaluate retail service quality. Stores have to concentrate more on these factors to improve RSQ. These store attributes have a strong positive impact on customer satisfaction and leads to Patronage intention and positive word of mouth (WOM).SStores have to reduce the complaints received from the customers and solve them immediately. This may create a good relationship between customers and store employees and patronage intention increases. Hence the researcher concluded that problem solving is the major issue faced by the retail stores and they have to take immediate action to maintain their loyal customer base.

\section{Limitations and future scope of the study}

The data were collected from the supermarkets and departmental store in [location masked for blind review] City, Tamil Nadu. Only organized retail outlets were studied for this paper. Future researchers may study on organized retail outlets or they can compare both organized and unorganized retail outlets. Researcher used five point Likert scale for this study to scaling the variables. Future researchers may use different scaling method for their study.

- Competing interests: The authors declare that they have no financial or personal relationship(s) that may have inappropriately influenced them in writing this article.

- Author contributions: Author of this paperdesigned and implemented the research, to the analysis of the results and to the writing of the manuscript.

- Funding:The author(s) received no financial support for the research, authorship, and/or publication of this article.

- Data availability: The authors confirm that the data supporting the findings of this study are available within the article [and/or] its supplementary materials.

Disclaimer:A statement to the effect that the views reflected in the article presented are his or her own and not the official stance of the organization or the funder.

\section{References}

1. Alam, M. M. D. (2018). The effect of service quality on customer loyalty of Generation Y-an empirical investigation on superstores in Bangladesh. Malaysian Management Journal, 22, 161-183.

2. Aldousari Abdullah A.and El-Sayed Ismail M. (2017). Factors influencing consumers' patronage intentions in Kuwait. Journal of Business and Retail Management Research (JBRMR), 11(3). Ali, M., \& Raza, S. A. (2017). Service quality perception and customer satisfaction in Islamic banks of Pakistan: the modified SERVQUAL model. Total Quality Management \& Business Excellence, 28(5-6), 559577.

3. Alić, A., Agić, E., \& Činjarević, M. (2017). The Importance of Store Image and Retail Service Quality in Private Brand Image-Building. Entrepreneurial Business and Economics Review, 5(1), 27-42, DOI: http://dx.doi.org/10.15678/EBER.2017.050102

4. Arif Hasan (2018).Evaluation of Factors Influencing Exclusive Brand Store Choice: An Investigation in the Indian Retail Sector. Vision, 22(4) 416-424, https://doi.org/10.1177/0972262918803489

5. Barnes, D.C., Collier, J.E., Howe, V. and Douglas Hoffman, K. (2016), "Multiple paths to customer delight: the impact of effort, expertise and tangibles on joy and surprise", Journal of Services Marketing, 30(3), pp. 277-289.

6. Bhat, I. H. (2016). Validating a retail service quality instrument in grocery specialty stores. International Journal of Information, Business \& Management, 8(2), 205-217.

7. Carpenter, J.M., Moore, M., (2006). Consumer demographics, store attributes, and retail format in the US grocery market. Int. J. Retail Distrib. Manag. 34 (6), 434-453.

8. Casidy, R. and Wymer, W. (2015), 'The impact of brand strength on satisfaction, loyalty and WOM: an empirical examination in the higher education sector', Journal of Brand Management, 22(2), pp. 117 135. 
9. Chen, L., Li, Y.-Q., \& Liu, C.-H. (2019). How airline service quality determines the quantity of repurchase intention-Mediate and moderate effects of brand quality and perceived value. Journal of Air Transport Management, 75, 185-197.

10. Chiu Y.K., Lin. C .Y (2012). The Influence of Spokes-Characters on Consumer Patronage Intention. Asia Pacific Management Review, 17(4), 421-435

11. Dabholkar, P. A., Thorpe, D. I., \& Rentz, J. O. (1996). A measure of service quality for retail stores: Scale development and validation. Journal of the Academy of Marketing Science, 24(1), 3-16.

12. Diallo M. F. (2012). Effects of store image and store brand price-image on store brand purchase intention: Application to an emerging market. Journal of Retailing and Consumer Services, 19, 360367.

13. Diallo, M.F., Coutelle-Brillet, P., Riviere, A., Zielke, S., (2015). How do price perceptions of different brand types affect shopping value and store loyalty? Psychol. Mark. 32 (12), 1133-1147.

14. Duncan, T.R., Moriarty, S., (2006). How integrated marketing communication's 'touch points' can operationalize the service-dominant logic? In: Vargo, S.L., Lusch, R.F. (Eds.), The Service-dominant Logic of Marketing: Dialog, Debate and Directions. ME Sharpe, Armonk, NY, pp. 236-243.

15. eMarketer (2017). 'Worldwide retail and ecommerce sales: eMarketer's estimates for 2016-2021, available at: www.emarketer.com/Report/Worldwide-Retail-Ecommerce-SaleseMarketers-Estimates20162021/2002090

16. Ertekin, N., et al (2019). Assessing Impacts of Store and Salesperson Dimensions of Retail Service Quality on Consumer Returns. Production and Operations Management, https://doi.org/10.1111/j.19375956.2019.13077.x

17. Euphemia F.T. Yuen and Sian S.L. Chan (2010). The effect of retail service quality and product quality on customer loyalty.Journal of Database Marketing \& Customer Strategy Management, 17, 222-240.

18. Evanschitzky, H., Ramaseshan, B., Woisetschläger, D. M., Richelsen, V., Blut, M. \& Backhaus, C. (2012). Consequences of customer loyalty to the loyalty program and to the company. Journal of the Academy of Marketing Science, 40(5), 625-638.

19. Fernandes, T., Calamote, A., (2016). Unfairness in consumer services: outcomes of differential treatment of new and existing clients. Journal of Retailing and Consumer Services, 28, 36-44.

20. Grosso, M., Castaldo, S., \& Grewal, A. (2018). How store attributes impact shoppers' loyalty in emerging countries: An investigation in the Indian retail sector. Journal of Retailing and Consumer Services, 40, 117-124.

21. Halseth, G., \& Ryser, L. (2006). Trends in service delivery: examples from rural and small town Canada, 1998 to 2005. The Journal of Rural and Community Development, 1, 69-90

22. Harrison-Walker, L.J., (2001). The measurement of word of mouth communication and an investigation of service quality and customer commitment as potential antecedents. Journal of Service Research. 4 (1), 60-75.

23. Hernant, M. and Rosengren, S. (2017), 'Now what? evaluating the sales effects of introducing an online store', Journal of Retailing and Consumer Services, Vol. 39, pp. 305-313

24. J. Beneke C. Hayworth R. Hobson Z. Mia (2012). Examining the effect of retail service quality dimensions on customer satisfaction and loyalty: The case of the supermarket shopper, Acta Commercii, pp27-43

25. Jain, P., \& Aggarwal, V. S. (2018). Developing a service quality scale in context of organized grocery retail of India. Management Decision, 56(9), 1969-1990.

26. Jiang, Sin Jie, 'Physical Appearance in Retail Service: Impact on Customer Loyalty and Experience' (2017).MBA Student Scholarship. 59.

27. Kamran-Disfani, O., Mantrala, M. K., Izquierdo-Yusta, A., \& Martinez-Ruiz, M. P. (2017). The impact of retail store format on the satisfaction-loyalty link: An empirical investigation. Journal of Business Research, 77, 14-22.

28. Karjaluoto, H., Munnukka, J., \& Kiuru, K. (2016). Brand love and positive word of mouth: the moderating effects of experience and price. Journal of Product \& Brand Management, 25(6), 527-537. https://doi.org/10.1108/ JPBM-03-2015-0834

29. Kasiri, L. A., Cheng, K. T. G., Sambasivan, M., \& Sidin, S. M. (2017). Integration of standardization and customization: Impact on service quality, customer satisfaction, and loyalty. Journal of Retailing and Consumer Services, 35(2), 91-97.

30. Khan, I., Rahman, Z., (2015). Brand experience anatomy in retailing: an interpretive structural modeling approach. Journal of Retailing and Consumer Services, 24, 60-69.

31. Ko, LK, Enzler, C., Perry, CK, Rodriguez, E., Mariscal, N., Linde, S., \& Duggan, C. (2018). Food availability and food access in rural agricultural communities: use of mixed methods. BMC Public Health, 18 (1), 1-9. https://doi.org/10.1186/s12889-018-5547-x. 
32. Konuk, F. A. (2018). The role of store image, perceived quality, trust and perceived value in predicting consumers' purchase intentions towards organic private label food. Journal of Retailing and Consumer Services, 43, 304-310.

33. Lau, M., Cheung, R., Lam, A. and Chu, Y. (2013), 'Measuring service quality in the banking industry: a Hong Kong based study', Contemporary Management Research, Vol. 9 No. 3, pp. 263-283.

34. Lehner, M., (2015). Translating sustainability: the role of the retail store. International Journal of Retail distribution Management.43 (4/5), 386-402

35. Ltifi, M., \& Gharbi, J. (2015). The Effect of Logistics Performance in Retail Store on the Happiness and Satisfaction of Consumers. Procedia Economics and Finance, 23, 1347-1353.

36. Maggioni, I. (2016). What drives customer loyalty in grocery retail? Exploring shoppers' perceptions through associative networks. Journal of Retailing and Consumer Services, 33, 120-126.

37. Mahmoud, A. B., Ekwere, T., Fuxman, L., \& Meero, A. A. (2019). Assessing patients' perception of health care service quality offered by COHSASA-accredited hospitals in Nigeria. SAGE Open, 9(2). https://doi.org/10.1177/2158244019852480

38. Media Reports(2019), Press Releases, Deloitte report, Department of Industrial Policy and Promotion website, Union Budget 2019-20, Consumer Leads report by FICCI and Deloitte - October (2019).

39. Mengi, P. (2009), 'Customer satisfaction with service quality: an empirical study of public and private sector banks', Journal of Management Research, Vol. 8 No. 9, pp. 7-17.

40. Nadiri, H., Hussain, K., Ekiz, E.H. and Erdogan, S. (2008), "An investigation on the factors influencing passengers' loyalty in the North Cyprus national airline”, The TQM Journal, Vol. 20 No. 3, pp. 265280.

41. Nair, S.R., (2018). Analyzing the relationship between stores attributes satisfaction, patronage intention and lifestyle in food and grocery store choice behavior. International Journal of Retail Distribution Management, 46 (1), 70-89.

42. Ng, P.F., Butt, M.M., Khong, K.W., Ong, F.S., (2014). Antecedents of green brand equity: an integrated approach. Journal of Business Ethics, 121 (2), 203-215.

43. Nyadzayo, M.W. and Khajehzadeh, S. (2016), The antecedents of customer loyalty: a moderated mediation model of customer relationship management quality and brand image, Journal of Retailing and Consumer Services, Vol. 30, pp. 262-270.

44. Osakwe, C. N. (2019). Understanding customer-perceived quality in informal stores. Journal of Services Marketing, 33(2), 133-147.

45. Otterbring, T., Wastlund, E., Gustafsson, A., \& Shams, P. (2014). Vision (im) possible? The effects of in-store signage on customers' visual attention. Journal of Retailing and Consumer Services, 21, 676684.

46. Özgür Çengel, Ilgin Çakiroğlu (2020).Impact of Mall attractiveness on Mall Patronage Intention: The mediating effect of Mall Personality. International Journal of Commerce and Finance, 6(1), 204-226.

47. Park, C.W., MacInnis, D.J., Priester, J., Eisingerich, A.B., Iacobucci, D., (2010). Brand attachment and brand attitude strength: Conceptual and empirical differentiation of two critical brand equity drivers. Journal of Marketing, 74 (6), 1-17.

48. Porral Cristina Calvo and Mark F. Lang (2015). Private labels: The role of manufacturer identification, brand loyalty and image on purchase intention. British Food Journal 117(2), pp. 506-522.

49. Prakash, G. (2019). Understanding service quality: Insights from the literature. Journal of Advances in Management Research, 16(1), 64-90.

50. Prentice, C., Wang, X., \& Lin, X. (2018). An organic approach to customer engagement and loyalty. Journal of Computer Information Systems. Advance online publication. https://doi.org/10.1080/08874417.2018.1485528

51. Quach, S., Jebarajakirthy, C., \& Thaichon, P. (2017). Aesthetic labor and visible diversity: The role in retailing service encounters. Journal of Retailing and Consumer Services, 38, 34-43.

52. Rimkus, L., Isgor, Z., Ohri-Vachaspati, P., Zenk, S., Powell, LM, Barker, D., \& Chaloupka, F. (2015). Disparities in the availability and price of low-fat and higher-fat milk in US food stores by community characteristics. Journal of the Academy of Nutrition and Dietetics, 115 (12), 1975-1985. https://doi.org/10.1016/j.jand.2015.04.002.

53. Roy, S., Sreejesh, S., \& Bhatia, S. (2019). Service quality versus service experience: An empirical examination of the consequential effects in B2B services. Industrial Marketing Management, 82, 52-69.

54. Sarker, M. A. R., \& Ashrafi, D. M. (2018). The relationship between internal marketing and employee job satisfaction: A study from retail shops in Bangladesh. Journal of Business and Retail Management Research, 12(3), 149-159.

55. Sekaran, U., \& Bougie, R.(2016), Research methods for business: a skill-building approach (7th ed.). Haddington: John Wiley \& Sons. 
56. Seth, N., Deshmukh, S.G. and Vrat, P. (2005), 'Service quality models: a review', International Journal of Quality and Reliability Management, 22(9), pp. 913-949.

57. Shafiq, A., Mostafiz, M.I. and Taniguchi, M. (2019) 'Using SERVQUAL to determine Generation Y's satisfaction towards hoteling industry in Malaysia', Journal of Tourism Futures, 5(1), pp.62-74.

58. Sharma, S. and Srivastava, S. (2018) 'Relationship between service quality and customer satisfaction in hotel industry', TRJ Tourism Research Journal, 2(1), pp.42-49.

59. Shi, Y., Lim, J.M., Weitz, B.A., France, S.L., (2018). The impact of retail format diversification on retailers' financial performance. Journal of Academic Marketing Science 46 (1), 147-167.

60. Siddiqi, K.O. (2011), 'Interrelations between service quality attributes, customer satisfaction and customer loyalty in the retail banking sector in Bangladesh', International Journal of Business and Management, 6(3), pp. 12-36.

61. Slack, N., Singh, G. and Sharma, S. (2020), 'The effect of supermarket service quality dimensions and customer satisfaction on customer loyalty and disloyalty dimensions', International Journal of Quality and Service Sciences. http://dx.doi.org/10.1108/IJQSS-10-2019-0114

62. Smigielska, G., \& Oczkowska, R. (2017). Retailers' competitiveness on global markets. International Entrepreneurship| Przedsiębiorczość Międzynarodowa, 3(1), 175-196.

63. Sonali Diddi and Linda S. Niehm (2017).Exploring the role of values and norms towards consumers' intentions to patronize retail apparel brands engaged in corporate social responsibility (CSR). Fashion and textiles. 4(5).pp.1-20. https://doi.org/10.1186/s40691-017-0086-0

64. Srivastava, M. and Kaul, D. (2016), 'Exploring the link between customer experience-loyaltyconsumer spend', Journal of Retailing and Consumer Services, 31(1), pp. 277-286.

65. Su, L., Swanson, S.R., Chinchanachokchai, S., Hsu, M.K. and Chen, X. (2016), 'Reputation and intentions: the role of satisfaction, identification, and commitment', Journal of Business Research, 69(9), pp. 3261-3269.

66. Suja R. Nair, (2017) "Analyzing the relationship between store attributes, satisfaction, patronage intention and lifestyle in food and grocery store choice behavior", International Journal of Retail \& Distribution Management, https://doi.org/10.1108/IJRDM-06-2016-0102

67. Sunil, M.P., Shobharani, H., Mathew, A.K. and Rose, A.E. (2018) 'Validation of SERVQUAL model in star hotels pertaining to Bengaluru City’, Asian Journal of Management, 9(1), pp.393-399.

68. Terblanche NS and Boshoff C (2006). The relationship between a satisfactory in-store shopping experience and retailer loyalty.South African Journal of Business Management, 37(2).

69. Torlak, O., Uzkurt, C. \& Ozmen, M. (2010), 'Dimensions of service quality in grocery retailing: a case from Turkeye, Management Research Review, 33(5), pp. 413-422.

70. Trusov, M., Bucklin, R.E., Pauwels, K., (2009). Effects of word-of-mouth versus traditional marketing: findings from an internet social networking site. Journal of Marketing, 73 (5), 90-102.

71. Vlachos, P.A., Vrechopoulos, A.P., (2012). Consumer-retailer love and attachment: antecedents and personality moderators. J. Retail. Consum Serv. 19 (2), 218-228.

72. Wu P.C.S, Yeh G.Y.Y., Hsiao C.R. (2011). The effect of store image and service quality on brand image and purchase intention for private label brands. Australasian Marketing Journal, Vol.19, pp.3039.

73. Xu, X., \& Li, Y. (2016). The antecedents of customer satisfaction and dissatisfaction toward various types of hotels: A text mining approach. International Journal of hospitality management, 55(1), 57-69.

74. Yeng, W. F., \& Yazdanifard, R. (2015). Opportunities and Challenges in the World of Retailing and the Importance of Adaption to the New Markets. International Journal of Management, Accounting and Economics, 2(9), 1110-1121.

75. Yoon, S.J., (2013). Antecedents and consequences of in-store experiences based on an experiential typology. Eur. J. Mark. 47 (5/6), 693-714.

76. Zaim, H., Bayyurt, N. and Zaim, S. (2010), 'Service quality and determinants of customer satisfaction in hospitals: Turkish experience', The International Business and Economics Research Journal, 9(5), pp. 51-58. 